\title{
Development of Comprehensive Yoga Program for Cervical Carcinoma
}

\section{Govardhan HB, Noopur Nelson, Khaleel and Manisha Roy}

Department of Radiation Oncology, Kidwai Memorial Institute of Oncology, India

*Corresponding author: Govardhan HB, Department of Radiation Oncology, Kidwai Memorial Institute of Oncology, India, Tel: 9971058822; E-mail: yogakidwai@gmail.com

Received date: February 23, 2018; Accepted date: March 02, 2018; Published date: March 25, 2018

Copyright: @ 2018 Govardhan HB, et al. This is an open-access article distributed under the terms of the Creative Commons Attribution License, which permits unrestricted use, distribution, and reproduction in any medium, provided the original author and source are credited.

\section{Abstract}

Background: Prior research reveal the benefits of yoga in managing fatigue, stress and psychosocial outcomes in cervical carcinoma; however, a definite structured yoga program is unavailable. In this study an effort is made to develop and validate a structured yoga program for cervical carcinoma.

Methods: A detailed review of ancient and contemporary yoga literature was conducted to design a basic yoga program. Five yoga experts, who fulfilled the inclusion criteria validated the program. 27 practices were rated as (i) not essential, (ii) useful but not essential, and (iii) essential; Lawshe's content validity ratio (CVR) was calculated.

Results: Eighteen practices exhibited significant content validity (cut-off value: 0.99 , as calculated by applying Lawshe's formula for the CVR). One practice was added to the module by the experts, making a total of 19 practices including meditation. Yoga nidra was added as a special practice on days of high fatigue.

Conclusions: The designed program received good content validity and thus is valid for cervical cancer. The program is to be applied on patients to assess its acceptability and feasibility.

Keywords Yoga; Cancer; Integrative care; Development; Palliative care; Supportive care

\section{Introduction}

After breast cancer the incidence of cervical cancer is the highest in women worldwide, resulting in lack of vitality and diminished quality of life [1]. Human Papilloma Virus (HPV) infection causes more than $90 \%$ of the cases [2]. Over 500,000 new diagnosis and mortality of over 250,000 deaths was recorded (2012) [3]. Developing countries account for $80 \%$ of the world burden, due to ineffective control programs and screening [4]. Early-stages can be effectively cured. Chemoradiotherapy is the standard of care; Concurrent Cisplatinbased chemotherapy is advocated with Immunotherapy and hormonal replacement therapy [5-8].

Cervical cancer treatment presents with side effects which cause interruption in treatment outcomes, financial and psychosocial difficulties. Recurrent treatment remains largely ineffective hampering daily life [5].

Alternative methods have been adopted, of which Yoga is one. Significant difference was observed with yoga in quality of life, stress, emotional status, fluctuation in mood, depression, anger and confusion [9]. Literature on the effect of yoga on breast carcinoma is available, but no literature on the development of yoga module as an adjuvant therapy along with chemo-radiotherapy for cervical cancer patients [10].

\section{Methods}

\section{Structuring integrated yoga module for cervical cancer}

Integrated Yoga Module is structured by reviewing ancient yogic classical texts, recent research publication and other recent Yoga publications.

\section{Yoga experts}

Experts were chosen among Oncologists, doctorate $(\mathrm{PhD})$ in Yoga and therapists holding minimum experience of 3 years.

\section{Inclusion Criteria}

- Classical texts of Yoga therapy, research publication, recent books and journals and research thesis which has the descriptions of Yoga for cancer

- To check the content validity, Yoga clinicians (MD - Yoga) / Yoga doctorates (PhD - Yoga) with minimum experience of 5 years in the field and Yoga instructor with at least 3 years' experience after post formal education, in association with oncologists.

- Consented to the study.

\section{Exclusion criteria}

- Yoga therapists with less than 3 years' experience.

- Yoga instructors dealing with healthy individuals only.

\section{Design}

Classical Yoga text books contemplate few postures and techniques which can be advocated for Cancer. To develop the protocol, following steps were followed: 
Page 2 of 5

Step1: Review of classical text and research literature: Classical texts, recent books on Yoga for Cervical cancer and other cancers, relevant dissertation/ thesis and research publications were referred for the development of the Yoga programme.

Step2: Development of Yoga module: Research studies on yoga published in scientific journals were extracted. Relevant practices were included in the Yoga module.

Step3: Validation of Yoga module: Validation was done with the help of 5 experts on a three point scale (0 to 2), 2 for essential, 1 for useful but not essential and 0 for not necessary.

Step 4: Data analysis: Results were tabulated and analysed using Lawshe's Content Validity Ratio (CVR) to check the content validity [11].

Step 5: Report writing: The final outcome report of the study conducted, inclusive of the results and discussion is formatted.

\section{Data analysis}

The content validity was calculated using Lawshe Method (1975), If $\mathrm{E}$ denotes the number of experts marking a domain as essential and $\mathrm{N}$ the total number of experts, then Lawshe's CVR is defined as the ratio of $(\mathrm{Ne}-\mathrm{N} / 2)$ and N/2 which arrive at the critical values as per Lawshe (1975). Where, $\mathrm{Ne}=$ total no. of Essentials for each practice and $\mathrm{N}=$ total no of panellists. The mean CVR represents the overall content validity.

\section{Results}

The CVR ratio for all practices of the module is 0.762 for 5 experts.

Table 1 Shows CVR of Yoga practices of Integrated Yoga module as per Lawshe formula. As per the Lawshe's CVR ratio the minimum value for 5 experts is 0.99 , the CVR ratio achieved is slightly lower, however a larger expert panel will better the acceptance of the module.

In this study, Nine practices viz; Griva Shithilikarana (0.2), Bhuja Shithilikarana (0.2), Gulpha Shithilikarana (0.6), Moon pose (0.6) Padahasthasana (0.6) Pashchimottanasana (0.2), Bhujangasana (0.2), Ardha Shalabhasana (0.6) and Kapalabhatti (-1) were insignificant. All other practices were considered to satisfy the minimum value to be achieved.

Based on the comments of the yoga experts, the butterfly practice with fast/slow flapping for 2 minutes was included into the program to aid circulation, stretch and relax abdomen. Yoga Nidra was suggested to be performed on days of chemotherapy when the fatigue scores are high. The finalised yoga program consisted of 20 practices (Table 2).

\section{Total duration: 60 minutes}

All the above practices have been used in various RCT studies and the experts opine that these practices can be performed by cancer patients. However, the severity of any pain, GI disturbances and fatigue should be taken into consideration at every session. There are more chances of acceptability of this Yoga module, hinting towards a more positive effect with minimum negative effect if any.

\begin{tabular}{|l|l|l|l|l|l|l|}
\hline SI No & Specific Practice & Ne & N & N/2 & Ne-N/2 & CVR \\
\hline 1 & Griva Shithilikarana & 3 & 5 & 2.5 & 0.5 & 0.2 \\
\hline 2 & Bhuja Shithilikarana & 3 & 5 & 2.5 & 0.5 & 0.2 \\
\hline 3 & Kati Shithilikarana & 5 & 5 & 2.5 & 2.5 & 1 \\
\hline
\end{tabular}

\begin{tabular}{|l|l|l|l|l|l|l|}
\hline 4 & Janu Shithilikarana & 5 & 5 & 2.5 & 2.5 & 1 \\
\hline 5 & Gulpha Shithilikarana & 4 & 5 & 2.5 & 1.5 & 0.6 \\
\hline 6 & Hands in and out breathing & 5 & 5 & 2.5 & 2.5 & 1 \\
\hline 7 & Hand stretch Breathing & 5 & 5 & 2.5 & 1.5 & 1 \\
\hline 8 & Tiger Breathing & 5 & 5 & 2.5 & 2.5 & 1 \\
\hline 9 & Moon Pose breathing & 4 & 5 & 2.5 & 1.5 & 0.6 \\
\hline 10 & Quick Relaxation Technique & 5 & 5 & 2.5 & 2.5 & 1 \\
\hline 11 & Ardhakati chakrasana & 5 & 5 & 2.5 & 1.5 & 1 \\
\hline 12 & Ardha Chakrasana & 5 & 5 & 2.5 & 1.5 & 1 \\
\hline 13 & Padahasthasana & 4 & 5 & 2.5 & 0.5 & 0.6 \\
\hline 14 & Pashchimottanasana & 3 & 5 & 2.5 & 0.5 & 0.2 \\
\hline 15 & Ardha Matsyendrasana & 5 & 5 & 2.5 & 2.5 & 1 \\
\hline 16 & Setubandhasana & 5 & 5 & 2.5 & 2.5 & 1 \\
\hline 17 & Suptaudarakarshanasana & 5 & 5 & 2.5 & 1.5 & 1 \\
\hline 18 & Ardha Pavanamukthasana & 5 & 5 & 2.5 & 2.5 & 1 \\
\hline 19 & Bhujangasana & 3 & 5 & 2.5 & 0.5 & 0.2 \\
\hline 20 & Ardha Shalabhasana & 4 & 5 & 2.5 & 1.5 & 0.6 \\
\hline 21 & Deep relaxation Technique & 5 & 5 & 2.5 & 2.5 & 1 \\
\hline 22 & Kapalabhati & 1 & 5 & 2.5 & -1.5 & -0.6 \\
\hline 23 & Vibhagya Pranayama & 5 & 5 & 2.5 & 2.5 & 1 \\
\hline 24 & Nadishuddi & 5 & 5 & 2.5 & 2.5 & 1 \\
\hline 25 & Bhramari Pranayama & 5 & 5 & 2.5 & 1.5 & 1 \\
\hline 26 & Nadanusandhana & 5 & 5 & 2.5 & 2.5 & 1 \\
\hline 27 & Om Dhyana & 5 & 5 & 2.5 & 1.5 & 1 \\
\hline & Average & 5 & 2.5 & 1.648 & 0.763 \\
\hline
\end{tabular}

Table 1: Shows CVR of Yoga practices of Integrated Yoga module as per Lawshe formula1.

\begin{tabular}{|l|l|l|l|l|}
\hline $\begin{array}{l}\text { S } \\
\text { No. }\end{array}$ & Practice (Sanskrit) & Practice (English) & Rounds & $\begin{array}{l}\text { Time } \\
\text { (minutes) }\end{array}$ \\
\hline 1 & Kati Shithilikarana & Waist rotation & 3 & 1 \\
\hline 2 & Janu Shithilikarana & Knee tightening & 3 & 1 \\
\hline 3 & Shvasa kriya & Hands in \& out & 3 & 3 \\
\hline 4 & Shvasa kriya & Hand stretch Breathing & 3 & 3 \\
\hline 5 & $\begin{array}{l}\text { Vyaghra shvasana } \\
\text { Kriya }\end{array}$ & $\begin{array}{l}\text { Tiger breathing } \\
\text { Breathing }\end{array}$ & 3 & 3 \\
\hline 7 & $\begin{array}{l}\text { Ardha } \\
\text { Chakrasana }\end{array}$ & Katick Relaxation & 1 & 4 \\
\hline
\end{tabular}


Page 3 of 5

\begin{tabular}{|c|c|c|c|c|}
\hline & & Right half & 1 & 1 \\
\hline & & Left half & 1 & 1 \\
\hline 8 & Ardha Chakrasana & Half wheel posture & 1 & 1 \\
\hline \multirow[t]{3}{*}{9} & $\begin{array}{l}\text { Ardha } \\
\text { Matsyendrasana }\end{array}$ & Half spinal twist & & \\
\hline & & Right half & 1 & 1 \\
\hline & & Left half & 1 & 1 \\
\hline \multirow{2}{*}{10} & \multirow{2}{*}{ Butterfly Asana } & Fast movements & 1 & 2 \\
\hline & & Slow & 1 & 2 \\
\hline 11 & Setubandhasana & Bridge pose & 3 & 3 \\
\hline \multirow{3}{*}{12} & \multirow{3}{*}{$\begin{array}{l}\text { Supta } \\
\text { Udarakarshanasana }\end{array}$} & Folded leg stretch & & \\
\hline & & Right leg & 3 & 6 \\
\hline & & Left leg & 3 & \\
\hline \multirow[t]{3}{*}{13} & $\begin{array}{l}\text { Ardha } \\
\text { Pavanamuktasana }\end{array}$ & $\begin{array}{l}\text { Half wind releasing } \\
\text { pose }\end{array}$ & & \\
\hline & & Right side & 1 & 1 \\
\hline & & Left side & 1 & 1 \\
\hline 14 & & $\begin{array}{ll}\text { Deep } & \text { Relaxation } \\
\text { technique }\end{array}$ & 1 & 5 \\
\hline \multirow[t]{4}{*}{15} & $\begin{array}{l}\text { Vibhagya } \\
\text { Pranayama }\end{array}$ & Sectional Breathing & & \\
\hline & & Abdominal & 3 & \\
\hline & & Thoracic & 3 & 4 \\
\hline & & Shoulder & 3 & \\
\hline 16 & Nadi Shuddi & $\begin{array}{l}\text { Alternate } \quad \text { nostril } \\
\text { Breathing }\end{array}$ & 9 & 4 \\
\hline 17 & $\begin{array}{l}\text { Bhramari } \\
\text { Pranayama }\end{array}$ & Low pitch chant & 5 & 2 \\
\hline \multirow{4}{*}{18} & \multirow{4}{*}{ Chanting } & AA chant & 9 & \\
\hline & & UU chant & 9 & \\
\hline & & MM chant & 9 & 5 \\
\hline & & AUM chant & 9 & \\
\hline 19 & Om Dhyana & Om Meditation & & 5 \\
\hline 20 & Yoga Nidra & On days with Chemo & 1 & 5 \\
\hline
\end{tabular}

Cancer can affect the society as a financial burden, personal burden by loss of function, depression, pain followed with role changes and dependence.

Results indicate personal burden (high level of pain, fatigue, and depression associated with cancer) and low quality of life have higher adverse effect [14].

Globally yoga therapy has received widespread acceptance as a complementary and alternative practice for a range of diseases. Growing evidences compel CAM practitioners to adopt Yoga therapy. Several schools of Yoga (Asana based, Pranayama based, Meditation based) are set up, having their own approach in treating cancer.

\section{Rationale for using yoga intervention in cervical cancer}

The mind and body act in coordination through yoga enhancing mood and relieve pain.

Reports highlighting the beneficial effect of meditation and yoga amongst breast cancer patients are available. It can similarly be applied to cervical cancer. As yoga affects both the physical and mental entities of the body, improvement in the quality of life is achieved.

It integrates awareness of breath rendering deep relaxation. Yoga can effectively manage symptoms like distress, compromised sleep and fatigue [15]. Meditation improves the psychosocial aspects of cáncer [16]. Regular practice boosts the self-esteem [17].

There is no prior mention of a standardized integrated Yoga module, exclusive for cervical cancer patients. In this study, an effort was made to develop a yoga module by using available evidences and textual references, to be implemented for 4 weeks with personalised 60 minute duration sessions.

Around 25 research studies from different schools of Yoga on Oncology and 15 Yoga and Ayurveda related classical and recent books on Cancer were referred to formulate the module.

The Yoga practices were finalised based on the content validity criteria. After thorough literature review, the module was drafted and validated by Yoga experts.

The module was developed for 60 minutes by the yoga experts and each practice was reviewed in detail with oncologists, oncology nursing staff and supporting oncology staff to finalise the practices feasible for the patients (Table 3).

Data analysis revealed a CVR ratio of 0.762 for all 27 yoga practices of formulated yoga module for Cervical cancer. The final results of the protocol to be achieved by Lawshe' CVR ratio is 0.99 for 5 experts involved in the study. The limitation being, even if one of the practices receives a score less than maximum (2, essential practice), the overall CVR will drop to $>0.99$. Thus, validation by larger number of experts can result in better acceptance. Practices for which CVR was less than 0.99 were excluded from the module.

Table 2: Evaluated/recommended integrated Yoga module for Cervical Cancer as per the CVR ratio.

\section{Discussion}

Cervical cancer affects women in the productive age of 40-60 years [12]. Risk factors are compromised immunity, Contraceptive pills, early marriage and multiple sex partners [13]. 
Citation: Govardhan HB, Nelson N, Khaleel, Roy M (2018) Development of Comprehensive Yoga Program for Cervical Carcinoma. J Integr Oncol 7: 206. doi:10.4172/2329-6771.1000206

Page 4 of 5

\begin{tabular}{|c|c|c|}
\hline Practices & Experimental/Journal Reference & Classical reference/Book reference \\
\hline \multicolumn{3}{|l|}{ Specific Practices } \\
\hline \multicolumn{3}{|l|}{ 1. Loosening Exercises } \\
\hline $\begin{array}{l}\text { a. Neck Movements } \\
\text { b. Shoulder movements } \\
\text { c. Waist twisting } \\
\text { d. Knee tightening } \\
\text { e. Ankle rotation }\end{array}$ & $\begin{array}{l}\text { Monro, R et al (1990) Yoga for Common Ailments', Eds. Nanay Ford Kohna A, } \\
\text { Gaia origina, Pub: Simon \& Schuster Inc, New York, London, } 14 .\end{array}$ & (Nagaratna et al., 1990) \\
\hline \multicolumn{3}{|l|}{ 2. Breathing Techniques } \\
\hline $\begin{array}{l}\text { a. Hands in \& out } \\
\text { b. Hand Stretch } \\
\text { c. Rhythmic tiger breathing } \\
\text { d. Shashankasana Breathing }\end{array}$ & $\begin{array}{l}\text { Siedentopf, F et al. (2013) Yoga for patients with early breast cancer and its } \\
\text { impact on quality of life-a randomized controlled trial. }\end{array}$ & (Nagaratna et al, 2012) \\
\hline \multicolumn{3}{|l|}{ 3. Asana- Standing (wall support) } \\
\hline $\begin{array}{l}\text { a. Ardh Kati Chakrasana } \\
\text { b. Ardha Chakrasana } \\
\text { c. Pada Hastasana }\end{array}$ & $\begin{array}{l}\text { Bijlani, R. L et al (2005) A brief but comprehensive lifestyle education program } \\
\text { based on yoga reduces risk factors for cardiovascular disease and diabetes } \\
\text { mellitus. Journal of Alternative \& Complementary Medicine, 11(2), 267-274. }\end{array}$ & (Nagaratna et al., 1990) \\
\hline \multicolumn{3}{|l|}{ 4. Asana -Sitting Postures } \\
\hline a. Paschimottanasana & Dandawate et al (2010). Magic of ayurveda ad yoga: A overview. & $\begin{array}{l}\text { Asana Pranayama Mudra Bandha } \\
\text { (Swami Satyananda, 2013) }\end{array}$ \\
\hline b. Ardha Matsyendrasana & $\begin{array}{l}\text { Lee, M., Moon, W., \& Kim, J. (2014) Effect of yoga on pain, brain-derived } \\
\text { neurotrophic factor, and serotonin in premenopausal women with chronic low } \\
\text { back pain. Evidence-Based Complementary and Alternative Medicine, } 2014 \text {. }\end{array}$ & Hatha Yoga Pradeepika (2013) \\
\hline \multicolumn{3}{|l|}{ 5. Asana-Supine } \\
\hline $\begin{array}{l}\text { a. Sethu bandhasana } \\
\text { b. Folded leg lumbar stretch } \\
\text { c. Ardha Pavanamuktasana }\end{array}$ & $\begin{array}{l}\text { Mustian et al (2013). Multicenter, randomized controlled trial of yoga for sleep } \\
\text { quality among cancer survivors. Journal of Clinical Oncology, } 31(26), 3233-3241 \text {. }\end{array}$ & Asana Pranayama Mudra (2012) \\
\hline \multicolumn{3}{|l|}{ 6. Asana-Prone } \\
\hline a. Bhujangasana & $\begin{array}{l}\text { Littman, A. J. et al (2012) Randomized controlled pilot trial of yoga in overweight } \\
\text { and obese breast cancer survivors: effects on quality of life and anthropometric } \\
\text { measures. Supportive Care in Cancer, } 20(2), 267-277 .\end{array}$ & Light on Yoga (lyengar, 2011) \\
\hline b. Ardha shalabhasana & & Nagaratna et al., (1990) \\
\hline \multicolumn{3}{|l|}{ 7. Pranayama } \\
\hline $\begin{array}{l}\text { a. Kapalabhati } \\
\text { b. Vibhagya Pranayama (Sectional } \\
\text { Breathing) } \\
\text { - Abdominal } \\
\text { - Thoracic } \\
\text { - Clavicular } \\
\text { c. Nadi Shuddi } \\
\text { d. Bhramari } \\
\text { e. Ujjayi Pranayama }\end{array}$ & $\begin{array}{l}\text { Chakrabarty, J. et al (2015). Effectiveness of pranayama on cancer-related fatigue } \\
\text { in breast cancer patients undergoing radiation therapy: A randomized controlled } \\
\text { trial. International journal of yoga, } 8(1), 47 \text {. } \\
\text { Rao et al (2008). Effects of yoga on natural killer cell counts in early breast cancer } \\
\text { patients undergoing conventional treatment. Comment to: recreational music- } \\
\text { making modulates natural killer cell activity, cytokines, and mood states in } \\
\text { corporate employees. Medical Science Monitor, 14(2), LE3-LE4. }\end{array}$ & Hatha Yoga Pradeepika, (2013) \\
\hline \multicolumn{3}{|l|}{ 8. Relaxation } \\
\hline \multicolumn{3}{|l|}{$\begin{array}{l}\text { a. Quick relaxation } \\
\text { b. Deep relaxation }\end{array}$} \\
\hline 9. Meditation & $\begin{array}{l}\text { Kang, G., \& Oh, S. (2012) Effects of mindfulness meditation program on } \\
\text { perceived stress, ways of coping, and stress response in breast cancer } \\
\text { patients. Journal of Korean Academy of Nursing, } 42(2), 161-170 \text {. }\end{array}$ & \\
\hline
\end{tabular}




\section{a. Nadanusandhana}

b. Om meditation
Vadiraja, S. H. et al (2009) Effects of yoga on symptom management in breast

cancer patients: a randomized controlled trial. International journal of yoga, 2(2), Nagaratna et al., (1990) 73.

Table 3: Literature reviews of Yoga practices used for Cervical Cancer module.

Nine practices viz; Griva Shithilikarana (0.2), Bhuja Shithilikarana (0.2), Gulpha Shithilikarana (0.6), Moon pose (0.6), Padahasthasana (0.6) Pashchimottanasana (0.2), Bhujangasana (0.2), Ardha Shalabhasana (0.6) and Kapalabhatti $(-1)$ were not found to be significant to Cervical cancer. Griva shithilikarana and Bhuja shithilikarana were considered insignificant as they do not target cervical cancer complaints.

Padahasthasana, Pashchimotanasana, Bhujangasana and Ardha Shalabhasana were removed due to difficulty in performing and raise in abdominal pressure, pain and discomfort. Thus, these practices do not qualify to be included in the program.

Four out of 5 experts opined that the butterfly practice should be included into the program as it helps in increasing tone and relax the pelvic region.

Viparita karani was suggested by only two experts so it was not added into the module. All the experts suggested the inclusion of yoga nidra at the end of the session on days the patient presents with high fatigue scores/ day of chemotherapy.

A total of 19 practices were finalised with an addition of butterfly practice making it a total of 20 practices. The module was sent to the experts again for a finalising. No further changes were suggested by the experts.

\section{Conclusion}

Integrated Yoga module consists of 20 practices for Cervical cancer which were constructed based on literature review. The Integrated Yoga module validated by a panel of 5 yoga experts and oncologists, revealed that, among 27 yoga practices, 18 were found to be essential $(\mathrm{CVR} \geq 0.99)$ and 9 were found to be not essential (CVR $\leq 0.99)$. One practice was added to the module by the experts, making a total of 19 practices including meditation. Yoga Nidra was added as a special practice on days of high fatigue.

The present validation brings greater acceptability of Yoga therapy module for Cervical cancer. Addition of one practice was made based on the suggestions from the expert authors. A panel of greater number of experts would fetch higher CVR scores for the current module. There is scope for more research to evaluate effect of Yoga practice and its mechanism.

\section{Acknowledgements}

This study was supported by Ministry of Ayush, Government of India.

\section{References}

1. Munoz N, Bosch FX, Sanjose S, Herrero R, Castellsague X, et al. (2003) Epidemiologic classification of human papillomavirus types associated with cervical cancer. N Engl J Med 348: 518-527.
2. Franco EL, Franco ED, FerenczyA (2001) Cervical cancer: epidemiology, prevention and the role of human papillomavirus infection. Canadian Medical Association Journal1 64: 1017-1025.

3. Torre LA, Bray F, Siegel RL, Ferlay J, Lortet TJ, et al. (2015) Global cancer statistics, 2012. CA: a cancer journal for clinicians 65: 87-108.

4. Sankaranarayanan R, Budukh AM, Rajkumar R (2001) Effective screening programmes for cervical cancer in low-and middle-income developing countries. Bulletin of the World Health Organization 79: 954-962.

5. Waggoner SE (2003). Cervical cancer. The Lancet 361: 2217-2225.

6. Rose PG, Bundy BN, Watkins EB, Thigpen JT, Deppe G, et al. (1999) Concurrent cisplatin-based radiotherapy and chemotherapy for locally advanced cervical cancer. New England Journal of Medicine 340: 1144-1153.

7. Su JH, Wu A, Scotney E,Ma B, Monie A, et al. (2010) Immunotherapy for cervical cancer. BioDrugs 24: 109-129.

8. Ploch E (1987) Hormonal replacement therapy in patients after cervical cancer treatment. Gynecologic oncology 26: 169-177.

9. Bese NS, Hendry J, Jeremic B (2007) Effects of prolongation of overall treatment time due to unplanned interruptions during radiotherapy of different tumor sites and practical methods for compensation. International Journal of Radiation Oncology• Biology• Physics 68: 654-661.

10. Reed SNC, Carlson L, Daroux L, Aldous SH (2004) Discovering the physical and psychological benefits of yoga for cancer survivors. International Journal of Yoga Therapy 14: 45-52.

11. Raghavendra RM, Nagarathna R, Nagendra HR, Gopinath KS, Srinat BS, et al. (2007) Effects of an integrated yoga programme on chemotherapy induced nausea and emesis in breast cancer patients. European journal of cancer care 16(6), 462-474.

12. Lawshe CH (1975) A quantitative approach to content validity. Personnel psychology 28: 563-575.

13. Meanwell CA, Kelly KA, Wilson S, Roginski C, Woodman C, et al. (1988) Young age as a prognostic factor in cervical cancer: analysis of population based data from 10022 cases. Br Med J (Clin Res Ed) 296: 386-391.

14. Louie KS, Sanjose S, Diaz M, Castellsagué X, Herrero R, et al. (2009). Early age at first sexual intercourse and early pregnancy are risk factors for cervical cancer in developing countries. British journal of cancer 100:1191-1197.

15. Mallath MK,Taylor DG, Badwe RA, Rath GK, Shanta V, et al. (2014) The growing burden of cancer in India: epidemiology and social context. The Lancet Oncology 15: 205-212.

16. DiStasio SA (2008) Integrating yoga into cancer care. Clinical Journal of Oncology Nursing 12:125-130.

17. Carlson LE, Ursuliak Z, Goodey E, Angen M, Speca M (2001) The effects of a mindfulness meditation-based stress reduction program on mood and symptoms of stress in cancer outpatients: 6-month followup. Supportive care in Cancer 9: 112-123. 